\title{
Solid state fermentation: An effective fermentation strategy for the production of L-asparaginase by Fusarium culmorum (ASP-87)
}

\author{
Anil Kumar Meghavarnam, Savitha Janakiraman* \\ Department of Microbiology and Biotechnology, Bangalore University, Bangalore 560056, Karnataka, India
}

\section{A R T I C L E I N F O}

\section{Keywords:}

Solid state fermentation

Soybean meal

Wheat bran

L-asparaginase

Fusarium culmorum

\begin{abstract}
A B S T R A C T
Production of L-asparaginase by Fusarium culmorum (ASP-87) isolated from tropical soil was investigated under solid state fermentation on a laboratory scale using sixty five (65) agro based materials. Among the different agro based materials evaluated, soybean meal supported maximum L-asparaginase production (7.21 U/gds). Various optimization strategies for the production of L-asparaginase were also carried out with soybean meal and it was observed that inoculum size of $1 \times 10^{8}$ spores $/ \mathrm{mL}$, day 6 of incubation period, $3 \mathrm{~mm}$ of particle size of the substrate, moisture content of $70 \%$, initial $\mathrm{pH}$ of 7.0 and temperature at $30{ }^{\circ} \mathrm{C}$ were found to be optimal for $\mathrm{L}$ asparaginase production. Supplementation of glucose $(0.1 \%)$ and ammonium chloride $(0.1 \%)$ enhanced L-asparaginase production to 1.7 fold. Mixed substrate fermentation using soybean meal and wheat bran in the ratio $(1: 1 \mathrm{w} / \mathrm{w})$ further enhanced production of L-asparaginase to 0.5 fold with a final yield of $18.91 \mathrm{U} / \mathrm{gds}$.
\end{abstract}

\section{Introduction}

Enzymes are proteins with biocatalytic activity that catalyze and speed up rate of various chemical reactions with substrate specificity by lowering the activation energy. Microbes are widely exploited and are the potential source of industrially important enzymes as they synthesize and secrete large amounts of extracellular enzymes. Fungal enzymes account for approximately $60 \%$ of commercially available enzymes. Enzymes produced by fungi are widely used in paper and pulp industries, leather industries, textiles, detergents, food and beverages and therapeutics. The therapeutic enzymes produced by fungi have been commonly used as anti-inflammatory, thrombolytics or anticoagulants and oncolytics as replacement for metabolic deficiency. A major application of therapeutic enzymes is in the chemotherapy of cancer.

L-asparaginase (L-asparagine amido hydrolase E.C.3.5.1.1) is an enzyme belonging to an amidase group which catalyzes the hydrolysis of the amino acid L-asparagine to L-aspartic acid and ammonia. It is widely used as a therapeutic agent for the treatment of acute lymphocytic leukemia (ALL) (mainly in children), Hodgkin's disease, acute myelocytic leukemia, chronic lymphocytic leukemia, lymphosarcoma treatment and melano sarcoma (Stecher et al., 1999; Verma et al., 2007). L-asparaginase also has significant applications in food industry to reduce the formation of carcinogenic acryl amides in deep fried potato (Pedreschi et al., 2008).

L-asparaginase is widely distributed among plants, animals and microbes. However, L-asparaginase from fungal source has gained much attention because of its stability, high productivity and easy cultural conditions.

Industrial production of L-asparaginase by bacteria and fungi has been previously achieved by submerged fermentation (SmF). Commercial production of L-asparaginase is carried out by using Escherichia coli and Erwinia chrysanthemi. Submerged fermentation has several disadvantages like huge volume of waste water generation and difficulties in effluent treatment process. (Datar, 1986). Solid state fermentation (SSF) has gained much interest during recent years and has emerged as an economical, alternative cost effective process for enzyme production by utilizing agricultural and agro industrial residues as substrates which are converted into products with high commercial value (Pandey, 1992). The use of SSF for production of enzymes has many advantages over submerged fermentation such as less production cost with better physiological properties, smaller reactor volume and cheaper fermentation media, higher production rate and easier downstream processing (Pandey et al., 1999; Bhargav, 2008). Solid substrates, mainly agro based materials are reportedly being utilized as substrates for the production of L-asparaginase (Swathi et al., 2014; Kumar et al., 2013; Hymavathi et al., 2009; Mishra, 2006; El-Bessoumy et al., 2004). These substrates act both as physical support and source of nutrients which influences enzyme production. Therefore, screening and selection of an appropriate substrate is an important step for commercial production of an enzyme.

We have previously reported the production strategy of L-

\footnotetext{
* Corresponding author.

E-mail address: drsvtj@yahoo.co.in (S. Janakiraman).
} 
asparaginase in F. culmorum (ASP-87) by submerged fermentation (Meghavarnam and Janakiraman, 2015). In the present study, we explore the possibility of using agro based materials as sole substrates for the better production of L-asparaginase by F. culmorum (ASP-87).

\section{Materials and methods}

\subsection{Substrates and chemicals}

Different agro based substrates were procured from mills and few substrates were purchased from the local market in Bengaluru, Karnataka, India. These substrates were dried and ground into smaller particles in a mill and the particle size of $1 \mathrm{~mm}$ was used for the experiment. Other media components used in the experiment were obtained from Hi-media (Mumbai, India). All the chemicals were of analytical reagent grade.

\subsubsection{Microorganism and culture conditions}

The fungus F. culmorum strain (ASP-87) used in the study was isolated from tropical soil. This fungus was tested for mycotoxin production and found to be negative for fumonisins and trichothecenes. The fungal culture was maintained on Potato Dextrose Agar (PDA) slants by periodically sub-culturing on PDA at $30^{\circ} \mathrm{C}$ and stored at $4{ }^{\circ} \mathrm{C}$.

\subsubsection{Inoculum preparation}

The culture medium used for inoculum preparation was modified Czapek-Dox medium containing g/L of, Glucose,2.0; L-asparagine,10.0; $\mathrm{KH}_{2} \mathrm{PO}_{4}, 1.52 ; \quad \mathrm{KCL}, 0.52 ; \quad \mathrm{MgSO}_{4} \cdot 7 \mathrm{H}_{2} \mathrm{O}, 0.52 ; \quad \mathrm{CuNO}_{3} \cdot 3 \mathrm{H}_{2} \mathrm{O}$, trace; $\mathrm{ZnSO}_{4} .7 \mathrm{H}_{2} 0$,trace; $\mathrm{FeSO}_{4} .7 \mathrm{H}_{2} 0$,trace; pH 7.5 (Saxena and Sinha, 1981). Modified Czapek-Dox broth was prepared, sterilized and inoculated with $F$. culmorum (ASP-87) spore suspension $\left(10^{7}\right.$ spores $/ \mathrm{mL}$ ). The culture was incubated at $30^{\circ} \mathrm{C}$ under static cultivation conditions for $96 \mathrm{~h}$. The mycelial mat obtained was homogenized with water using mortar and pestle under sterile conditions and used as inoculum for further experiments.

\subsection{Screening and preparation of solid substrates}

In total, sixty five (65) types of agro based materials were used. They are arecanut peel, banana peel, banana stem, barley, black gram husk, bengal gram husk, broken chana, broken red rice, broken wheat, coconut fiber, coconut oil cake, carob pod, coffee husk, colocasia, corn cob, corn flakes, corn flour, corn kernel, corn peel, cotton seed oil cake, dry copra waste, flat bean seed, flat bean peel, gram flour waste, green gram husk, green peas waste, groundnut oil cake, groundnut waste, groundnut shell, jack fruit seeds, jowar husk, lemon peel, linseed powder, musambi peel, mushroom, orange peel, paddy husk, paddy straw, pea husk, pea peel, pomegranate peel, potato peel, ragi bran, ragi flour, ragi straw, rajma seed, red gram husk, rice flour, rice husk, saw dust, seri waste, sesame oil cake, sooji, sorghum milling waste, soybean broken, soybean meal, sugarcane bagassae, sunflower oil cake, sweet potato, tamarind peel, tapioca, tea waste, urad dhal waste, wheat bran and wheat flour were screened for L-asparaginase production.

Five grams of each substrate was weighed separately in a $100 \mathrm{~mL}$ Erlenmeyer flask and moistened with distilled water (70\%) containing L-asparagine $(0.05 \% \mathrm{w} / \mathrm{w})$. The flasks were sterilized by autoclaving at $121{ }^{\circ} \mathrm{C}$ (15 psi) for $15 \mathrm{~min}$. After cooling, the flasks were inoculated with $1.0 \mathrm{~mL}$ of spore suspension $\left(10^{7}\right.$ spores $\left./ \mathrm{mL}\right)$. The contents of the flasks were mixed thoroughly and incubated at $30^{\circ} \mathrm{C}$ for 6 days (Kumar et al., 2013).

\subsubsection{Extraction of the enzyme}

After 6 days of incubation, L-asparaginase was extracted from substrates according to the method of Kumar et al. (2013). The substrate with fungal biomass was air dried under shade and fifty milliliter of water was added and kept on orbital shaker at $(150 \mathrm{rpm})$ for $30 \mathrm{~min}$. To optimize incubation period $1 \mathrm{~g}$ of substrate with fungal biomass was withdrawn periodically at regular intervals in aseptic condition and air dried under shade and taken in a beaker containing $10 \mathrm{~mL}$ of distilled water $(1: 10)$. The contents of flasks were kept on orbital shaker (150 rpm) for $30 \mathrm{~min}$. The extract was separated by squeezing through a muslin cloth and filtered through Whatman No. 1 filter paper. The filtered extract was centrifuged at $10,000 \mathrm{rpm}$ for $10 \mathrm{~min}$. The resultant supernatant was used as enzyme source for L-asparaginase assay.

\subsubsection{Determination of $L$-asparaginase activity}

L-asparaginase activity in the culture filtrates was determined by the method of Imada et al. (1973). The L-asparagine hydrolysis rate was determined by quantifying the ammonia liberated using Nessler's reagent. A blend of $0.5 \mathrm{~mL}$ of $0.04 \mathrm{ML}$-asparagine, $0.5 \mathrm{~mL}$ of enzyme extract, $0.5 \mathrm{~mL}$ of $0.05 \mathrm{M}$ Tris- $\mathrm{HCl}$ buffer (pH 7.2) and $0.5 \mathrm{~mL}$ of distilled water was incubated at $37^{\circ} \mathrm{C}$ for $30 \mathrm{~min}$ and $0.5 \mathrm{~mL}$ of $1.5 \mathrm{M}$ trichloroacetic acid (TCA) was added to stop the reaction. The ammonia liberated in the supernatant was determined spectrophotometrically by adding $0.2 \mathrm{~mL}$ of Nessler's reagent into tubes containing $0.1 \mathrm{~mL}$ of enzyme and $3.7 \mathrm{~mL}$ of distilled water and incubated at room temperature for $20 \mathrm{~min}$. The absorbance was measured at $450 \mathrm{~nm}$ and L-asparaginase activity was expressed as the amount of ammonia liberated per $\mathrm{mL}$ per minute under the standard assay conditions.

\subsection{Optimization studies for L-asparaginase production}

Soybean meal was used as the sole source of carbon for L-asparaginase production. The optimization studies were carried out by one factor at a time (OFAT) approach by varying only a single factor at a time and keeping the remaining factors constant. The effect of various physiological and nutritional parameters such as incubation period (4 days to 9 days), initial moisture content of the substrate $(40 \%, 50 \%$, $60 \%, 70 \%, 80 \%$ and $90 \%)$, particle size fine $(2 \mathrm{~mm})$, intermediate $(3 \mathrm{~mm})$ and coarse $(4 \mathrm{~mm})$, inoculum size $\left(10^{6}, 10^{7}, 10^{8}\right.$ and $10^{9}$ spores/mL), initial pH 4.0-9.0), incubation temperature (25, 28, 30, 33, 35 and $37^{\circ} \mathrm{C}$ ) on L-asparaginase production has been studied. The influence of supplementation of additional carbon sources such as glucose, maltose, lactose, sucrose, fructose, starch, cellulose, xylose and ribose at $0.1 \%(\mathrm{w} / \mathrm{w})$ and nitrogen sources such as ammonium chloride, ammonium nitrate, ammonium sulfate, potassium nitrate, sodium nitrate, urea, peptone, yeast extract, beef extract and tryptone at $0.1 \%$ $(\mathrm{w} / \mathrm{w})$ on L-asparaginase production has been studied. Samples were drawn continuously at $24 \mathrm{~h}$ intervals and the enzyme activity was determined. All the experiments were carried out in triplicates.

\subsection{Effect of combination of mixed substrates on $L$-asparaginase production}

The substrates soybean meal, carob pod, corn cob, corn kernel, gram husk, green peas, groundnut oil cake, jowar husk, mushroom powder, soybean flour, sugarcane bagassae, sunflower oil cake, urad dhal waste and wheat bran were used for mixed substrate fermentation in various combinations for enhanced production of L-asparaginase. Soybean meal was kept as constant and each substrate was mixed with soybean meal in $1: 1(\mathrm{w} / \mathrm{w})$ ratio and assessed for L-asparaginase production. The substrate combination of soybean mean and wheat bran was evaluated in different ratios $(1: 4,2: 3,1: 1,3: 2$ and $4: 1)(w / w)$ for L-asparaginase production. The fermentation was carried out with the parameters that were optimized by OFTA approach. Five grams of each combination of substrates was weighed separately in a $100 \mathrm{~mL}$ Erlenmeyer flask and moistened with distilled water $(70 \%)$ containing L-asparagine $(0.05 \%$ $\mathrm{w} / \mathrm{w})$. The flasks were sterilized by autoclaving at $121^{\circ} \mathrm{C}(15 \mathrm{psi})$ for $15 \mathrm{~min}$. After cooling, the flasks were inoculated with $1.0 \mathrm{~mL}$ of spore suspension $\left(10^{8}\right.$ spores $\left./ \mathrm{mL}\right)$. The contents of the flasks were mixed thoroughly and incubated at $30^{\circ} \mathrm{C}$ for 6 days. 


\subsection{Statistical analysis}

All the experiments were carried out in triplicates and the results were expressed as mean \pm SD using SPSS software (version 20.0). The statistical significance between mean values was accessed by ANOVA through Duncan's Multiple Range Test (DMRT) at significance level of $(\mathrm{p}<0.05)$.

\section{Results and discussion}

\subsection{Screening of various agro based materials for L-asparaginase production in F. culmorum (ASP-87)}

Solid substrate fermentation is a low cost method for the production of enzymes as it provides better process control, higher yields besides several other beneficial aspects (Prabhakar, 2005). Selection of appropriate substrates for the production of enzymes is crucial in solid substrate fermentation as it depends on several factors mainly related with the cost, nutritive value and availability of the substrate (Pandey et al., 2000). Owing to its importance in pharmaceutical as well as in food industries, there has been a paramount interest in developing methods for cheaper production of this enzyme. One alternative low cost method for the production of any enzyme is the use of SSF mainly using agricultural based materials as substrates. In our present study, a total of sixty five (65) agro based materials were used as substrates or as carbon source for L-asparaginase production by Fusarium culmorum (ASP-87) under SSF. Of the sixty five (65) various substrates used, soybean meal proved to be the most suitable substrate for growth and maximum production of L-asparaginase $(7.21 \mathrm{U} / \mathrm{gds})$ followed by sugarcane bagassae (6.95 U/gds), corn kernel (6.60 U/gds), wheat bran (6.28 U/ gds), corn cob and carob pod (6.16 U/gds) (Table 1). Our results were in accordance with the observations made with Aspergillus sp.
ALAA2000 (Abbas Ahmed et al., 2015), Fusarium equiseti (Hosamani and Kaliwal, 2011), Streptomyces sp. (Basha et al., 2009) and Pseudomonas aeruginosa 50071 (El-Bessoumy et al., 2004) which preferred soybean meal for the better production of L-asparaginase. Minimum production of L-asparaginase $(0.66-0.41 \mathrm{U} / \mathrm{gds})$ was assessed when arecanut peel, coconut fiber, gram flour waste, paddy husk, sorghum milling waste and wheat flour waste were used as substrates (Table 1). Overall, we observed that most of the substrates supported the growth and enzyme production under SSF but, however, with exception of few substrates such as banana peel, banana stem, saw dust and seri waste. This might be due to inappropriate physical properties such as particle size, geometry and compactness of the substrate (Krishna, 2005). Other substrates such as wheat bran, rice bran, sugarcane bagassae, rice husk, red gram husk, green gram husk, bengal gram husk, coconut oil cake, groundnut oil cake, cotton seed oil cake, corn cob, carob pod, paddy straw, corn pith, and tea waste have also been reported by different workers as suitable substrates for the production L-asparaginase (Elshafei and El-Ghonemy, 2015; Swathi et al., 2014; Ghosh et al., 2013; Makky, 2013; Kumar et al., 2013; Pallem et al., 2011; Hymavathi et al., 2009; Mishra, 2006). Swathi et al. (2014), Kumar et al. (2013) and Pallem et al. (2011) reported wheat bran as the most suitable substrate for increased yield of L-asparaginase in Beauveria bassiana (MSS 18/41), Cladosporium sp. and Fusarium oxysporum respectively. However, our study categorically revealed that soybean meal as the most suitable substrate for the enhanced production of L-asparaginase. Soybean meal is nothing but a byproduct in soybean processing industries, therefore as a carbon source may reduce the cost of the enzyme production. It is also used as a medium for the production of enzymes such as lipases (Vargas et al., 2008), xlyanases (Maciel et al., 2008), cellulases (Vitcosque et al., 2012) and polygalacturonase (Coffman et al., 2014). Moreover, the biochemical composition of soybean meal i.e. high protein (48-60\%) and low lignin content makes

Table 1

List of solid substrates (agro based materials) used for L-asparaginase production in Fusarium culmorum (ASP-87).

\begin{tabular}{|c|c|c|c|c|c|}
\hline Sl. no. & Substrate & Enzyme activity (U/gds) & Sl. no. & Substrate & Enzyme activity (U/gds) \\
\hline 1 & Arecanut peel & $0.66 \pm 0.28$ & 34 & Musambi peel & $1.91 \pm 0.14$ \\
\hline 2 & Banana peel & NG & 35 & Mushroom powder & $4.16 \pm 0.19$ \\
\hline 3 & Banana stem & NG & 36 & Orange peel & $2.5 \pm 0.25$ \\
\hline 4 & Barley & $1.48 \pm 0.27$ & 37 & Paddy husk & $0.54 \pm 0.07$ \\
\hline 5 & Black gram husk & $4.25 \pm 0.25$ & 38 & Paddy straw & $1.33 \pm 0.38$ \\
\hline 6 & Bengal gram husk & $3.33 \pm 0.28$ & 39 & Pea husk & $2.08 \pm 0.14$ \\
\hline 7 & Broken chana & $1.91 \pm 0.14$ & 40 & Pea peel & $3.25 \pm 0.25$ \\
\hline 8 & Broken red rice & $2.62 \pm 0.12$ & 41 & Pomegranate peel & $3.58 \pm 0.38$ \\
\hline 9 & Broken wheat & $3.16 \pm 0.14$ & 42 & Potato peel & $3.68 \pm 0.16$ \\
\hline 10 & Coconut fiber & $0.45 \pm 0.19$ & 43 & Ragi bran & $1.33 \pm 0.38$ \\
\hline 11 & Coconut oil cake & $1.91 \pm 0.14$ & 44 & Ragi flour & $0.58 \pm 0.14$ \\
\hline 12 & Carob pod & $6.16 \pm 0.28$ & 45 & Ragi straw & $1.16 \pm 0.28$ \\
\hline 13 & Coffee husk & $1.08 \pm 0.38$ & 46 & Rajma seed & $1.33 \pm 0.14$ \\
\hline 14 & Colocasia & $1.59 \pm 0.37$ & 47 & Red gram husk & $3.0 \pm 0.25$ \\
\hline 15 & Corn cob & $6.16 \pm 0.14$ & 48 & Rice flour & $1.25 \pm 0.25$ \\
\hline 16 & Corn flakes & $3.08 \pm 0.14$ & 49 & Rice husk & $1.83 \pm 0.38$ \\
\hline 17 & Corn flour & $2.45 \pm 0.19$ & 50 & Saw dust & NG \\
\hline 18 & Corn kernel & $6.60 \pm 0.12$ & 51 & Seri waste & NG \\
\hline 19 & Corn peel & $2.41 \pm 0.38$ & 52 & Sesame oil cake & $2.66 \pm 0.28$ \\
\hline 20 & Cotton seed oil cake & $2.91 \pm 0.14$ & 53 & Sooji & $2.12 \pm 0.45$ \\
\hline 21 & Dry copra waste & $2.36 \pm 0.37$ & 54 & Sorghum milling waste & $0.41 \pm 0.14$ \\
\hline 22 & Flat bean seed & $4.25 \pm 0.25$ & 55 & Soybean flour & $5.16 \pm 0.14$ \\
\hline 23 & Flat bean peel & $3.08 \pm 0.38$ & 56 & Soybean meal & $7.21 \pm 0.10$ \\
\hline 24 & Gram flour waste & $0.41 \pm 0.14$ & 57 & Sugarcane bagassae & $6.95 \pm 0.19$ \\
\hline 25 & Green gram husk & $3.37 \pm 0.12$ & 58 & Sunflower oil cake & $5.60 \pm 0.20$ \\
\hline 26 & Green peas waste & $5.58 \pm 0.14$ & 59 & Sweet potato & $3.33 \pm 0.38$ \\
\hline 27 & Groundnut oil cake & $4.33 \pm 0.28$ & 60 & Tamarind peel & $2.66 \pm 0.28$ \\
\hline 28 & Groundnut waste & $3.16 \pm 0.52$ & 61 & Tapioca & $3.11 \pm 0.12$ \\
\hline 29 & Groundnut shell & $2.58 \pm 0.14$ & 62 & Tea waste & $1.08 \pm 0.38$ \\
\hline 30 & Jack fruit seeds & $3.25 \pm 0.25$ & 63 & Urad dhal waste & $5.54 \pm 0.07$ \\
\hline 31 & Jowar husk & $5.08 \pm 0.14$ & 64 & Wheat bran & $6.28 \pm 0.30$ \\
\hline 32 & Lemon peel & $2.16 \pm 0.14$ & 65 & Wheat flour & $0.58 \pm 0.08$ \\
\hline 33 & Linseed oil cake & $1.58 \pm 0.14$ & & & \\
\hline
\end{tabular}

NG- No growth, U/gds = Units/gram dry substrate. Data given are the mean of three replicates \pm standard error $(P \leq 0.05)$. 


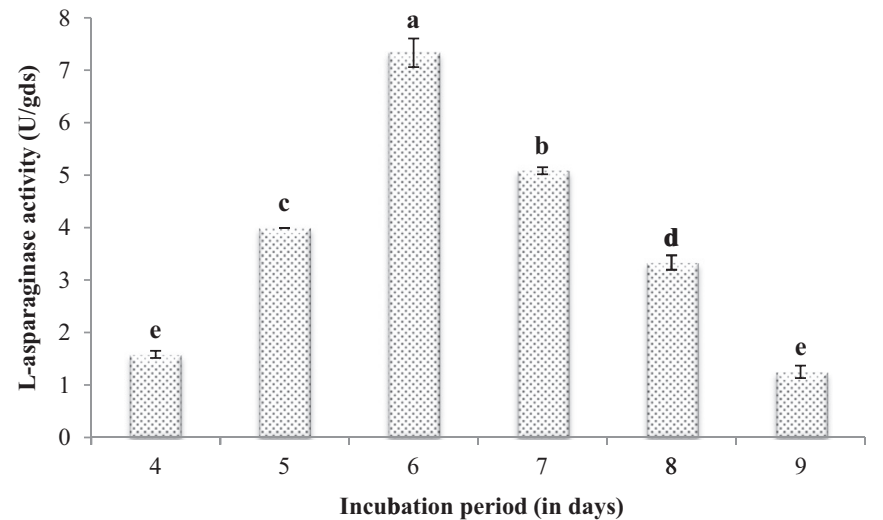

Fig. 1. Effect of incubation period on L-asparaginase production in F. culmorum (ASP-87) under SSF. In each series, mean values represented with the same lower case alphabets (a-e) are not significantly different (at $P<0.05$ ) according to DMRT.

it as an ideal substrate for the growth and production of L-asparaginase. Further studies were carried out with soybean meal as a substrate.

\subsection{Effect of incubation period}

Effect of fermentation period on L-asparaginase production by $F$. culmorum (ASP-87) in solid state fermentation was tested from 4 to 9 days of incubation with periodic testing of enzyme activity. Results of the present study revealed L-asparaginase production increased exponentially with increase in incubation period and attained maximum (7.33 U/gds) on the 6th day. However, further increase in incubation time gradually declined L-asparaginase production (Fig. 1). This might be because of the denaturation of the enzyme brought by the interaction with other constituents in the medium (Ramesh and Lonsane, 1987) or due to the depletion of nutrients that stimulates the production of secondary metabolites, resulting in lower yield of enzyme (Francis et al., 2002; Ramachandran et al., 2004). In our study, maximum production of L-asparaginase was obtained on day 6, whereas, Mishra (2006) and Kumar et al. (2013) reported maximum L-asparaginase production in Aspergillus niger and Cladosporium sp. on day 4 and 5 respectively.

3.2.1. Effect of initial moisture content, particle size of substrate and inoculum size

Among the several factors that are important for microbial growth and enzyme production under SSF, initial moisture content of the substrate, particle size of the substrate and size of the inoculum are the most critical factors that influence the growth, biosynthesis and secretion of different metabolites (Pandey et al., 2000; Ellaiah, 2002). The maximum L-asparaginase production $(7.33 \mathrm{U} / \mathrm{gds})$ was observed at $70 \%$ moisture content as reported in Aspergillus niger and Fusarium equiseti on different solid substrates (Mishra, 2006; Hosamani and Kaliwal, 2011). Further increase in moisture content of the fermentation medium however, led to the reduction of L-asparaginase production. This could be due to decrease in the porosity and agglomeration of particles, thereby limiting the oxygen transfer and therefore high vulnerability to bacterial contamination (Pandey, 2003; Hamidi-Esfahani, 2004; Sandhya, 2005). The activity of L-asparaginase decreased at lower (40\%) moisture content which may be due to reduced solubility of nutrients present in the solid substrate, lower degree of swelling and restriction of fungal growth thereby decreasing the enzyme yield (Fig. 2).

In SSF process, the availability of surface area of the substrate particle plays a vital role for microbial attachment, mass transfer of nutrients and enzyme production. L-asparaginase production was maximum $(7.16 \mathrm{U} / \mathrm{gds})$ with intermediate particle size $(3 \mathrm{~mm})$ of soybean meal (Fig. 3). Whereas, fine $(2 \mathrm{~mm})$ and coarse $(4 \mathrm{~mm})$ particle

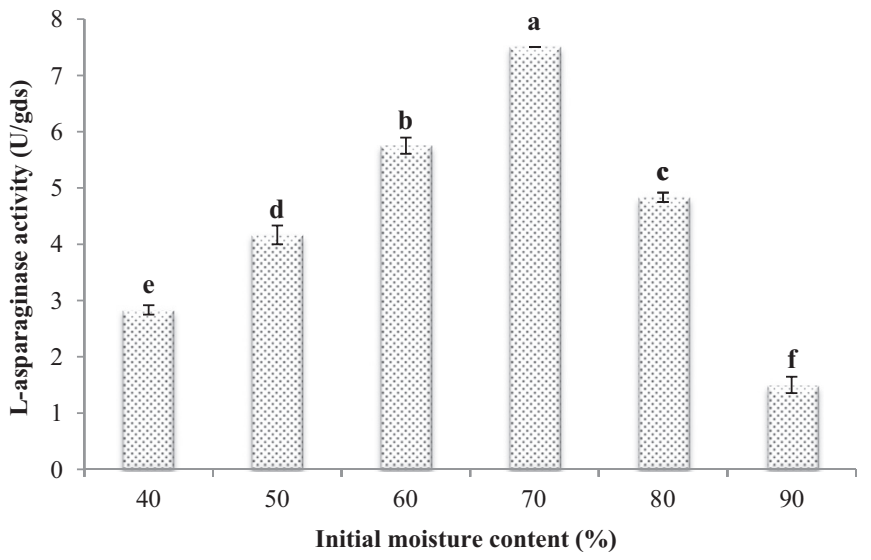

Fig. 2. Effect of initial moisture content on L-asparaginase production in F. culmorum (ASP-87) under SSF. In each series, mean values represented with the same lower case alphabets (a-f) are not significantly different (at $P<0.05$ ) according to DMRT.

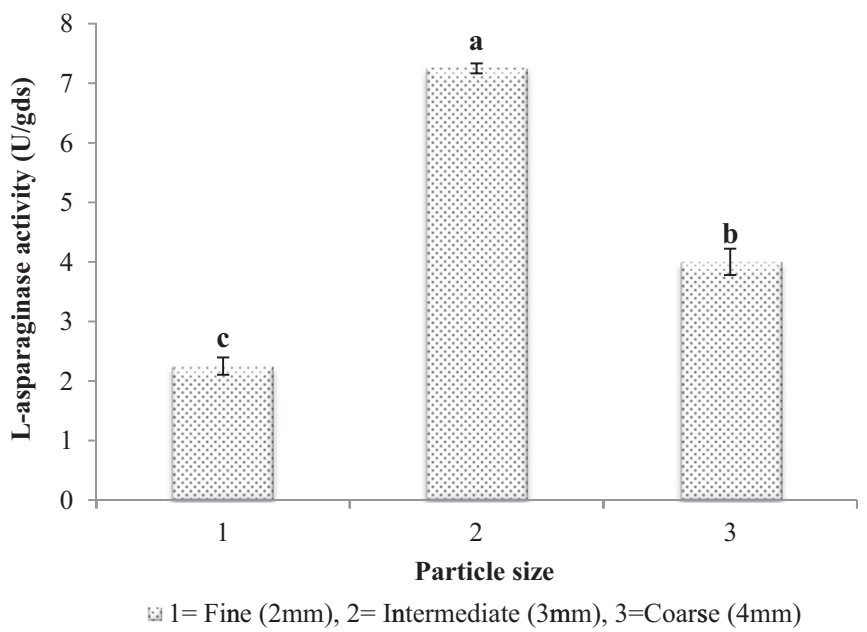

Fig. 3. Effect of particle size of substrate on L-asparaginase production in F. culmorum (ASP-87) under SSF. In each series, mean values represented with the same lower case alphabets $(\mathrm{a}-\mathrm{c})$ are not significantly different (at $P<0.05$ ) according to DMRT.

size resulted in decreased L-asparaginase production. This may be due to intra particulate associated aeration and limited surface area available for microbial attachment. Similar such observations were also made by Hosamani and Kaliwal (2011) in Fusarium equiseti when soybean meal was used as substrate.

In SSF process, the size of inoculum plays a significant role in the production of enzymes. We observed that L-asparaginase production increased with increase in inoculum size upto $1 \times 10^{8}$ spores $/ \mathrm{mL}(7.25$ $\mathrm{U} / \mathrm{gds}$ ) and further increase resulted in decreased enzyme production, although the growth was at maximum (Fig. 4). This could be due to depletion of nutrients within a shorter period, which would result in decreased metabolic activity (Kashyap et al., 2002). In general, lower inoculum size requires longer time for the cells to multiply and may not be sufficient for initiating microbial growth and enzyme production, whereas an increase in inoculum size would ensure rapid proliferation of biomass and subsequent enzyme synthesis (Sabu et al., 2005).

\subsubsection{Effect of initial $\mathrm{pH}$ and temperature}

Among the physical parameters, $\mathrm{pH}$ and temperature of the fermentation medium are the most critical parameters affecting the transport of various components across the cell membrane which in turn support the cell growth and product formation (Pandey et al., 2000; Krishna, 2005; Kapoor et al., 2008). However, in solid-state fermentations the $\mathrm{pH}$ is never controlled during fermentation, only the initial $\mathrm{pH}$ of the substrate is adjusted before inoculation. The optimum 


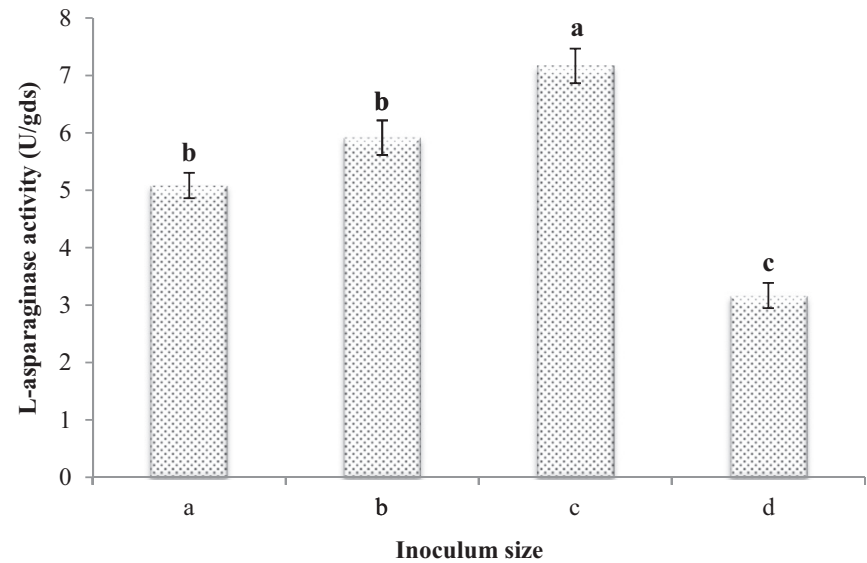

Fig. 4. Effect of inoculum size of substrate on L-asparaginase production in F. culmorum (ASP-87) under SSF. $\left(1=1 \times 10^{6}, 2=1 \times 10^{7}, 3=1 \times 10^{8}\right.$ and $4=1 \times 10^{9}$ spores/ gds). In each series, mean values represented with the same lower case alphabets (a-c) are not significantly different (at $P<0.05$ ) according to DMRT.

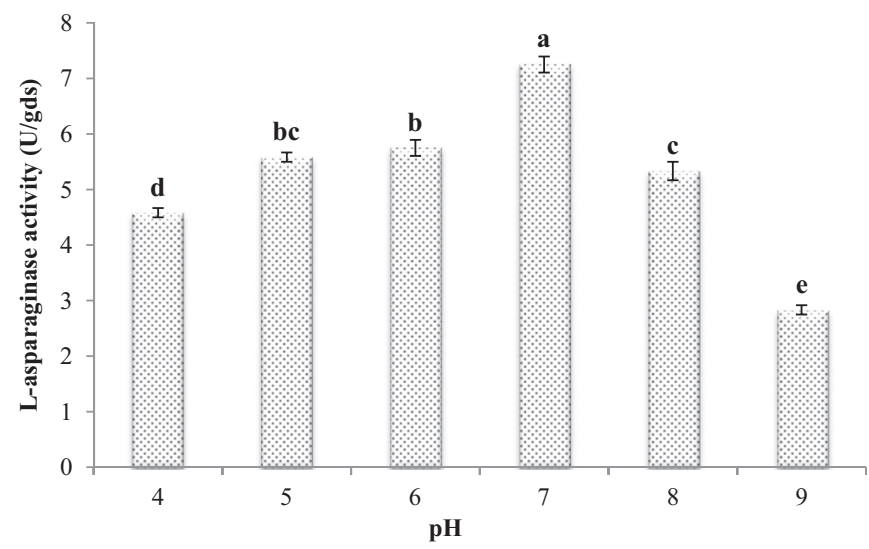

Fig. 5. Effect of initial $\mathrm{pH}$ on L-asparaginase production in F. culmorum (ASP-87) under SSF. In each series, mean values represented with the same lower case alphabets (a-e) are not significantly different (at $P<0.05$ ) according to DMRT.

$\mathrm{pH}$ for maximum production of L-asparaginase (7.33 U/gds) was observed when $\mathrm{pH}$ of the medium was adjusted to 7.0 (Fig. 5). Pallem et al. (2011) and Hosamani and Kaliwal (2011) also reported that an initial $\mathrm{pH}$ of 7.0 is most suited for L-asparaginase in Fusarium oxysporum and Fusarium equiseti when wheat bran and soybean meal was used as substrates. However, the enzyme activity decreased with increase in $\mathrm{pH}$ of the substrate beyond 7.0. This could be due to denaturation of enzymes by destruction of specific amino acid residues at higher $\mathrm{pH}$. Swathi et al. (2014) on the contrary, reported initial pH of 9.0 is optimum for Beauveria bassiana (MSS 18/41) when wheat bran was used as substrate. Maximum L-asparaginase production by Aspergillus terreus KLS 2 was observed at $\mathrm{pH} 4.5$ when carob pod was used as substrate (Siddalingeshwara et al., 2010). Thus, different fungal isolates have different $\mathrm{pH}$ optima for L-asparaginase production. This might be because fungal isolates respond distinctively to change in $\mathrm{pH}$ of the medium for enzyme production by providing ideal physiological $\mathrm{pH}$ for growth and development or by affecting the activity, structural stability and solubility of the enzyme.

L-asparaginase production gradually increased from 25 to $30{ }^{\circ} \mathrm{C}$ (Fig. 6) and maximum (7.66 U/gds) being at $30^{\circ} \mathrm{C}$. Further increase in temperature gradually decreased the enzyme production. This might be due to thermal denaturation of enzymes at higher temperature. In general, the temperature required for the production of enzymes in SSF is in the range of $25-32{ }^{\circ} \mathrm{C}$ (Lonsane et al., 1985). Our studies proved that optimum temperature for maximum production of L-asparaginase was $30{ }^{\circ} \mathrm{C}$. Similar findings were reported from Fusarium oxysporum and

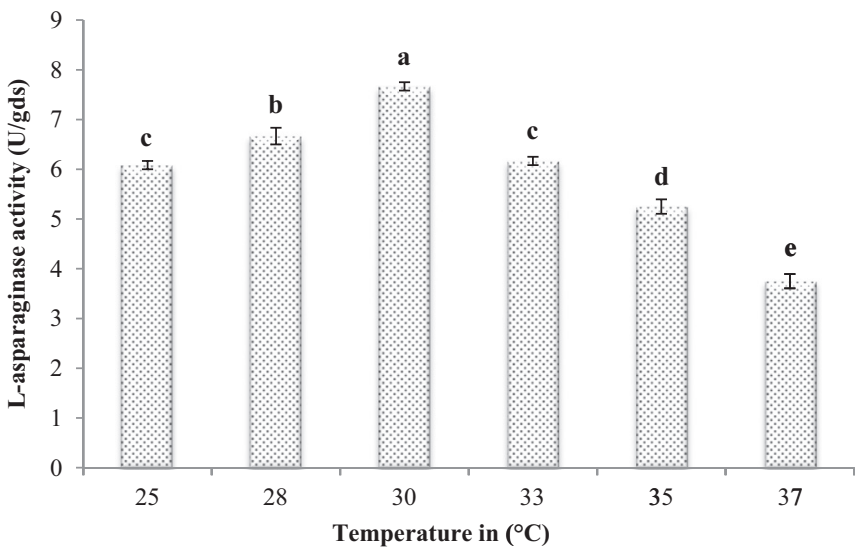

Fig. 6. Effect of temperature on L-asparaginase production in F. culmorum (ASP-87) under SSF. In each series, mean values represented with the same lower case alphabets (a-e) are not significantly different (at $P<0.05$ ) according to DMRT.

Cladosporium sp. by Pallem et al. (2011) and Kumar et al. (2013) respectively.

\subsubsection{Effect of supplementation of carbon and nitrogen sources}

The influence of supplementation of soybean meal with different carbon sources such as glucose, fructose, maltose, lactose, sucrose, starch, cellulose, xylose and ribose at $0.1 \%$ concentration on L-asparaginase production by $F$. culmorum (ASP-87) was studied. Addition of glucose resulted in maximum production of L-asparaginase $(8.41 \mathrm{U} /$ gds) followed by fructose (Fig. 7). Supplementation of substrate with xylose, ribose, sucrose and starch showed marginal increase in the production of L-asparaginase whereas, addition of maltose and cellulose resulted in decreased L-asparaginase production. Increase in the production of L-asparaginase with $0.1 \%$ glucose could be due to the fact that it is a simple and easily soluble sugar therefore, readily metabolized by fungi. It was also reported that glucose supported L-asparaginase production in other fungi such as Aspergillus terreus MTCC1782, Fusarium oxysporum and Trichoderma viride F2 (Gurunathan and Sahadevan, 2011; Pallem et al., 2011; Elshafei and El-Ghonemy, 2015). But on the other hand, glucose was also reported to be a repressor of Lasparaginase in Enterobacter aerogenes (Mukherjee et al., 2000). Further, to determine the optimum concentration of glucose as a supplement for L-asparaginase production, different concentrations $(0.5 \%, 1.0 \%, 1.5 \%$, $2.0 \% \mathrm{w} / \mathrm{w}$ ) of glucose was carried out. But however, above $0.1 \%$ inhibited the enzyme synthesis (data not shown) and therefore, $0.1 \%$ (w/

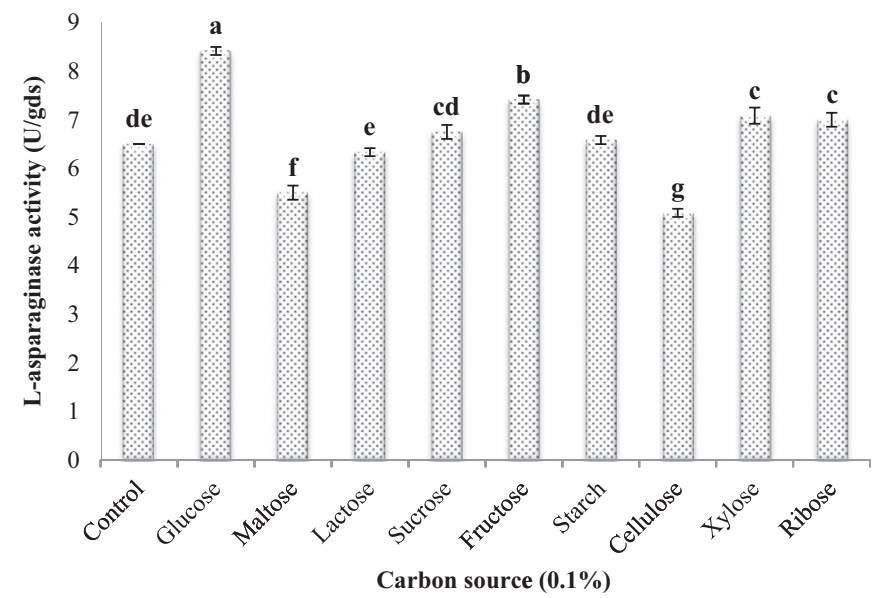

Fig. 7. Effect of supplementation of carbon sources on L-asparaginase production in $F$. culmorum (ASP-87) under SSF. In each series, mean values represented with the same lower case alphabets $(\mathrm{a}-\mathrm{g})$ are not significantly different (at $P<0.05$ ) according to DMRT. 


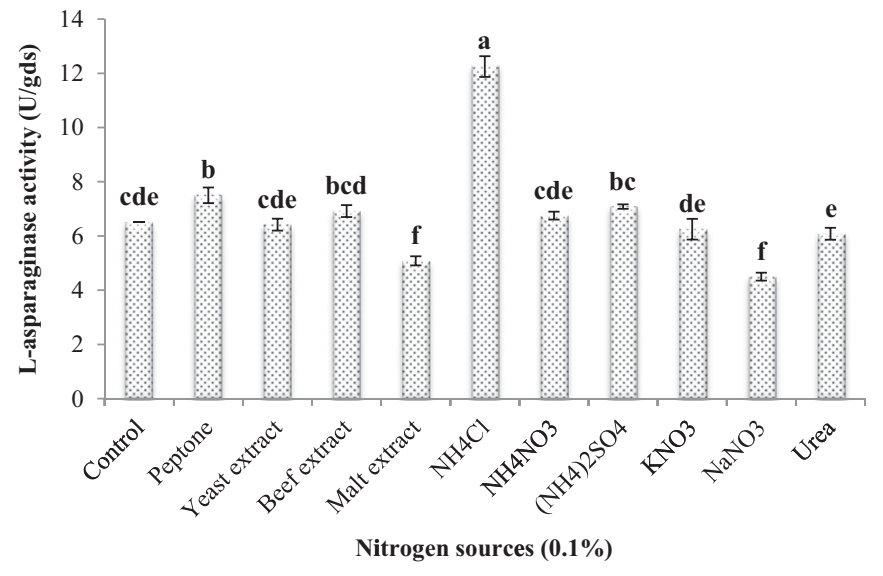

Fig. 8. Effect of supplementation of nitrogen sources on L-asparaginase production in $F$. culmorum (ASP-87) under SSF. In each series, mean values represented with the same lower case alphabets (a-f) are not significantly different (at $P<0.05$ ) according to DMRT.

w) of glucose is considered as the most optimum for L-asparaginase production in Fusarium culmorum (ASP-87).

The influence of supplementation of soybean meal with different organic and inorganic nitrogen sources such as peptone, yeast extract, beef extract, malt extract, ammonium chloride, ammonium nitrate, ammonium sulfate, potassium nitrate, sodium nitrate and urea at $0.1 \%$ concentration on L-asparaginase production by $F$. culmorum (ASP-87) was studied. Among all the nitrogen sources used, the maximum production of L-asparaginase $12.25 \mathrm{U} / \mathrm{gds}$ was observed when soybean meal was supplemented with $0.1 \%$ ammonium chloride followed by peptone with $7.5 \mathrm{U} / \mathrm{gds}$ activity (Fig. 8). Ammonium sulfate, ammonium nitrate and beef extract showed no significance in the production of L-asparaginase. However, addition of sodium nitrate and malt extract showed a negative effect resulting in decreased L-asparaginase production (Fig. 8). Pallem et al. (2011) and Elshafei and El-Ghonemy (2015) reported that malt extract and sodium nitrate enhanced the production of L-asparaginase in Fusarium oxysporum and Trichoderma viride F2 respectively. Hosamani and Kaliwal (2011) and Vijay and Raju (2014) reported ammonium sulfate enhanced the production of L-asparaginase in Fusarium equiseti and Aspergillus terreus MTCC 1782. Although soybean meal itself acts as nitrogen source in the growth medium, the influence of additional nitrogen source enhanced the production to 1.7 fold.

\subsection{Effect of mixed substrate fermentation}

Mixed solid substrates are viable substrates for SSF process (Benjamin and Pandey, 1998). Accordingly, a mixed SSF process was developed by mixing different substrates keeping soybean meal as constant. Interestingly, the mixture of soyabean meal with wheat bran increased the production of L-asparaginase (18.91 U/gds) in comparison to individual substrates alone followed by soybean meal with carob pod (12.33 U/gds) and soybean meal with fresh green peas (11.91 U/ gds) (Table 2). However, mixture of other substrates with soybean meal did not have much influence on L-asparaginase production. There were very few work done previously on the production of L-asparaginase by mixed SSF. Vijay and Raju (2014) reported mixed substrates of pearl millet and finger millet yielded maximum production of L-asparaginase by Aspergillus terreus MTCC 1782. This is the first report on L-asparaginase production using a mixture of soybean meal and wheat bran ( $2.5 \mathrm{~g}$ and $2.5 \mathrm{~g}$ respectively). Further, the effect of different ratios (1:4, $2: 3,1: 1,3: 2$ and $4: 1 \mathrm{w} / \mathrm{w}$ ) of soybean meal and wheat bran was evaluated for L-asparaginase production. The results revealed maximum Lasparaginase production when soybean meal and wheat bran (1:1) were used in equal proportions (Fig. 9). Maximum yield of L-asparaginase
Table 2

Effect of mixed substrates on L-asparaginase production in F. culmorum (ASP- 87) under SSF.

\begin{tabular}{ll}
\hline Substrates & Enzyme activity (U/gds) \\
\hline Soybean meal + Carob pod & $12.33 \pm 0.38$ \\
Soybean meal + Corn cob & $8.91 \pm 0.62$ \\
Soybean meal + Corn kernal & $9.16 \pm 0.14$ \\
Soybean meal + Gram husk & $8.58 \pm 0.38$ \\
Soybean meal + Green peas & $11.91 \pm 0.62$ \\
Soybean meal + Groundnut oil cake & $10.91 \pm 0.38$ \\
Soybean meal + Jowar husk & $7.33 \pm 0.14$ \\
Soybean meal + Mushroom powder & $9.16 \pm 0.38$ \\
Soybean meal + Soybean flour & $10.66 \pm 0.62$ \\
Soybean meal + Sugarcane bagassae & $9.25 \pm 0.5$ \\
Soyabean meal + Sunflower oil cake & $10.33 \pm 0.62$ \\
Soybean meal + Urad dhal waste & $8.83 \pm 0.38$ \\
Soybean meal + Wheat bran & $18.91 \pm 0.52$ \\
\hline
\end{tabular}

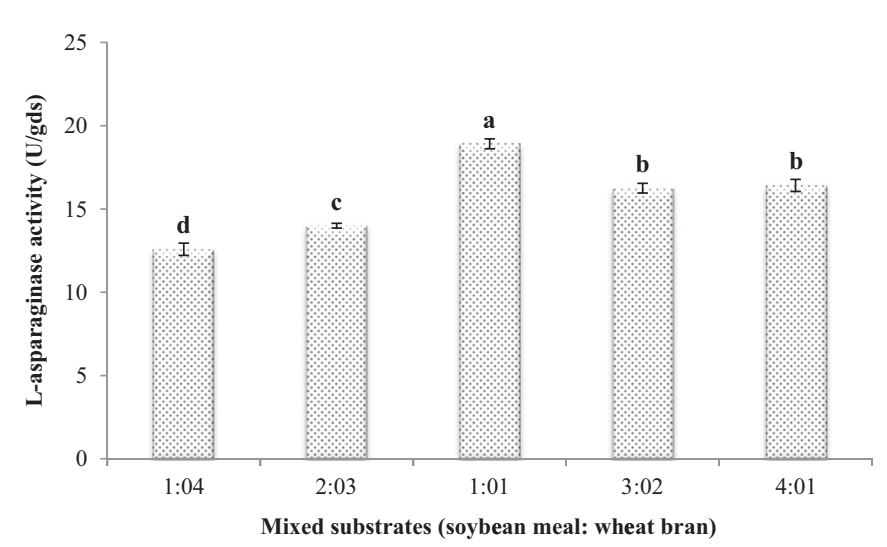

Fig. 9. Effect of mixed substrates on L-asparaginase production in F. culmorum (ASP-87) under SSF. In each series, mean values represented with the same lower case alphabets (a-d) are not significantly different (at $P<0.05$ ) according to DMRT.

was obtained (24.5 U/gds) under optimized conditions. (data not shown). Soybean meal is the by-product of soybean processing industries, which act as a rich source of proteins and amino acids. Wheat bran is used as universal substrate as it contains sufficient nutrients and remains free under high moisture content, providing a large surface area for growth of microorganism. Both the substrates as such are rich in nutrients and therefore, act as a good substrate for the production of L-asparaginase.

\section{Conclusion}

In conclusion, utilization of agro based materials through biotechnological process is gaining more significance with the dual goal of waste disposal and better production. L-asparaginase, a biotechnologically important enzyme is commercially produced by submerged fermentation. Owing to its importance in pharmaceutical and food industries, cost effective technologies are needed for large scale production. Very few reports are available on screening and optimization of L-asparaginase production under SSF and this study is one of the few. Our present study has explored the use of several agro based substrates as sole source of nutrients for the production of L-asparaginase by F. culmorum (ASP-87) under SSF. Major parameters affecting the fermentative process for L-asparaginase production in SSF were studied and optimal levels were identified which could be exploited for large scale production. Mixed substrate fermentation using soybean meal and wheat bran showed promising results for L-asparaginase production in SSF. Although SmF is globally accepted method for the production of commercially important enzymes, we report that for Lasparaginase production SSF is the most suitable fermentation process which shows 8.2 fold higher enzyme production than in SmF 
(Meghavarnam and Janakiraman, 2015).

\section{Acknowledgements}

The authors wish to express their gratitude to University Grant Commission (No. F.7-322/2011(BSR)) for Basic Science Research fellowship provided to Anil Kumar Meghavarnam and Department of Microbiology and Biotechnology, Bangalore University, Bengaluru for providing the facility.

\section{References}

Abbas Ahmed, M.M., Dahab, N.A.F., Taha, T.M., Hassan, F.S.M., 2015. Production purification and characterization of L-asparaginase from marine endophytic Aspergillus sp. ALAA-2000 under submerged and solid state fermentation. J. Microb. Biochem. Technol. 7, 165-172.

Basha, N.S., Rekha, R., Komala, M., Ruby, S., 2009. Production of extracellular antileukaemic enzyme L-asparaginase from marine actinomycetes by solid state and submerged fermentation: purification and characterisation. Trop. J. Pharm. Res. 8, 353-360.

Benjamin, S., Pandey, A., 1998. Mixed solid substrate fermentation: a novel process for enhanced lipase production by Candida rugosa. Acta Biotechnol. 18, 315-324.

Bhargav, S., Panda, B.P., Ali, M., Javed, S., 2008. Solid substrate fermentation: an overview. Chem. Biochem. Eng. 22, 49-70.

Coffman, A.M., Li, Q., Ju, L.K., 2014. Effect of natural and pretreated soybean hulls on enzyme production by Trichoderma reesei. J. Am. Oil Chem. Soc. 91, 1331-1338.

Datar, R., 1986. Economic of primary separation steps in relation to fermentation and genetic engineering. Process Biochem. 21, 19-26.

El-Bessoumy, A.A., Sarhan, M., Mansour, J., 2004. Production isolation and purification of L-asparaginase from Pseudomonas aeruginosa 50071 using solid-state fermentation. J. Biochem. Mol. Biol. 37, 387-393.

Ellaiah, P., Adinarayana, K., Bhavani, Y., Padmaja, P., Srinivasulu, B., 2002. Optimization of process parameters for glucoamylase production under solid state fermentation by a newly isolated Aspergillus species. Process Biochem. 38, 615-620.

Elshafei, A.M., El-Ghonemy, D.H., 2015. Screening and media optimization for enhancing L-asparaginase production, an anticancer agent from different filamentous fungi in solid state fermentation. Br. Biotechnol. J. 9, 1-15.

Francis, F., Sabu, A., Nampoothiri, K.M., Szakacs, G., Pandey, A., 2002. Synthesis of alpha-amylase by Aspergillus oryzae in solid state fermentation. J. Basic Microbiol. 42, 320-326.

Ghosh, S., Murthy, S., Govindasamy, S., Chandrasekaran, M., 2013. Optimization of Lasparaginase production by Serratia marcescens (NCIM2919) under solid state fermentation using coconut oil cake. Sustain. Chem. Process 1, 1-8.

Gurunathan, B., Sahadevan, R., 2011. Production of L-asparaginase from natural substrates by Aspergillus terreus MTCC 1728: optimization of carbon source and operating conditions. Int. J. Chem. React. Eng. 9, 1-15.

Hamidi-Esfahani, Z., Shojaosadati, S.A., Rinzema, A., 2004. Modeling of simultaneous effect of moisture and temperature on Aspergillus niger growth in solid-state fermentation. Biochem. Eng. J. 21, 265-272.

Hosamani, R., Kaliwal, B., 2011. Isolation, molecular identification and optimization of fermentation parameters for the production of L-asparaginase, an anticancer agent by Fusarium equiseti. Int. J. Microbiol. Res. 3, 108-119.

Hymavathi, M., Sathish, T., Rao, C.S., Prakasham, R.S., 2009. Enhancement of L-asparaginase production by isolated Bacillus circulans MTCC 8574 using response surface methodology. Appl. Biochem. Biotechnol. 159, 191-198.

Imada, A., Igarasi, S., Nakahama, K., Isono, M., 1973. Asparaginase and glutaminase activities of micro-organisms. J. Gen. Microbiol. 76, 85-99.

Kapoor, M., Nair, L.M., Kuhad, R.C., 2008. Cost effective xylanase production from free and immobilized Bacillus pumilus strain MK001 and its application in saccharification of Prosopis juliflora. Biochem. Eng. J. 38, 88-97.

Kashyap, P., Sabu, A., Pandey, A., Szakacs, G., 2002. Extra-cellular L-glutaminase production by Zygosaccharomyces rouxii under solid state fermentation. Process Biochem. 38, 307-312.

Krishna, C., 2005. Solid state fermentation systems-an overview. Crit. Rev. Biotechnol.
$25,1-30$.

Kumar, M.N.S., Ravi, R., Manonmani, H.K., 2013. Production and optimization of L-asparaginase from Cladosporium sp. using agricultural residues in solid substrate fermentation. Ind. Crops Prod. 43, 150-158.

Lonsane, B.K., Ghildyal, N.P., Budiatman, S., Ramakrishna, S.V., 1985. Engineering aspects of solid state fermentation. Enzym. Microb. Technol. 7, 258-265.

Maciel, G.M., de Souza Vandenberghe, L.P., Haminiuk, C.W.I., Fendrich, R.C., Della Bianca, B.E., da Silva Brandalize, T.Q., Pandey, A., Soccol, C.R., 2008. Xylanase production by Aspergillus niger LPB 326 in solid-state fermentation using statistical experimental designs. Food Technol. Biotechnol. 46, 183-189.

Makky, E.A., Ong, J.J., Karim, R.M., Lee, C.M., 2013. Production and optimization of Lasparaginase by Bacillus sp. KK2S4 from corn cob. Afr. J. Biotechnol. 12, 2654-2658.

Meghavarnam, A.K., Janakiraman, S., 2015. Optimization of physiological growth conditions for maximal production of L-asparaginase by Fusarium species. Int. J. Bioassays 4, 4369-4375.

Mishra, A., 2006. Production of L-asparaginase an anticancer agent from Aspergillus niger using agricultural waste in solid state fermentation. Appl. Biochem. Biotechnol. 135, 33-42.

Mukherjee, J., Majumdar, S., Scheper, T., 2000. Studies on nutritional and oxygen requirements for production of L-asparaginase by Enterobacter aerogenes. Appl. Microbiol. Biotechnol. 53, 180-184.

Pallem, C., Nagarjun, V., Srikanth, M., 2011. Production of a tumour inhibitory enzyme Lasparaginase through solid state fermentation using Fusarium oxysporum. Int. J. Pharm. Sci. Rev. Res. 7, 189-192.

Pandey, A., Selvakumar, P., Soccol, C.R., Nigam, P., 1999. Solid state fermentation for the production of industrial enzymes. Curr. Sci. 77, 149-162.

Pandey, A., 1992. Recent process developments in solid-state fermentation. Process Biochem. 27, 109-117.

Pandey, A., 2003. Solid-state fermentation. Biochem. Eng. J. 14, 81-84.

Pandey, A., Soccol, C.R., Mitchell, D., 2000. New developments in solid state fermentation: i-bioprocesses and products. Process Biochem. 35, 1153-1169.

Pedreschi, F., Kaack, K., Granby, K., 2008. The effect of asparaginase on acrylamide formation in French fries. Food Chem. 109, 386-392.

Prabhakar, A., Krishnaiah, K., Janaun, J., Bono, A., 2005. An overview of engineering aspects of solid state fermentation. Malays. J. Microbiol. 1, 10-16.

Ramachandran, S., Patel, A.K., Nampoothiri, K.M., Francis, F., Nagy, V., Szakacs, G. Pandey, A., 2004. Coconut oil cake - a potential raw material for the production of $\alpha$ amylase. Bioresour. Technol. 93, 169-174.

Ramesh, M.V., Lonsane, B.K., 1987. Solid-state fermentation for production of $\alpha$-amylase by Bacillus megaterium 16M. Biotechnol. Lett. 9, 323-328.

Sabu, A., Pandey, A., Daud, M.J., Szakacs, G., 2005. Tamarind seed powder and palm kernel cake: two novel agro residues for the production of tannase under solid state fermentation by Aspergillus niger ATCC 16620. Bioresour. Technol. 96, 1223-1228.

Sandhya, C., Sumantha, A., Szakacs, G., Pandey, A., 2005. Comparative evaluation of neutral protease production by Aspergillus oryzae in submerged and solid-state fermentation. Process Biochem. 40, 2689-2694.

Saxena, R.K., Sinha, U., 1981. L-asparaginase and glutaminase activities in the culture filtrates of Aspergillus nidulans. Curr. Sci. 50, 218-219.

Siddalingeshwara, K.G., Lingappa, K., 2010. Screening and optimization of L-asparaginase, a tumour inhibitor from Aspergillus terreus through solid state fermentation. J. Adv. Sci. Res. 1, 55-60.

Stecher, A.L., Morgante, P., De Deus, Polikarpov, I., Abrahao-Neto, J., 1999. Stability of Lasparaginase-an enzyme used in leukemia treatment. Pharm. Acta Helv. 74, 1-9.

Swathi, N., Kamalakumari, P.V., Girija, S.G., Prabhakar, T., 2014. Production of L-asparaginase by solid substrate fermentation using marine fungus. BioMed. Res. Biochem. 1, 1-9.

Vargas, G.D., Treichel, H., de Oliveira, D., Beneti, S.C., Freire, D.M., Di Luccio, M., 2008. Optimization of lipase production by Penicillium simplicissimum in soybean meal. J. Chem. Technol. Biotechnol. 83, 47-54.

Verma, N.K., Kumar, G., Kaur Anand, S., 2007. L-asparaginase: a promising chemotherapeutic agent. Crit. Rev. Biotechnol. 27, 45-62.

Vijay, B., Raju, K., 2014. Production of L-asparaginase by Aspergillus terreus MTCC 1782 under solid state fermentation using pearl millet and finger millet as mixed substrate. J. Chem. Biol. Phys. Sci. 5, 366-377.

Vitcosque, G.L., Fonseca, R.F., Rodriguez-Zuniga, U.F., Bertucci Neto, V., Couri, S., Farinas, C.S., 2012. Production of biomass-degrading multi enzyme complexes under solid-state fermentation of soybean meal using a bioreactor. Enzym. Res. 2012 (2012). 